\title{
Induction Therapy Epoch
}

National Cancer Institute

\section{Source}

National Cancer Institute. Induction Therapy Epoch. NCI Thesaurus. Code C123453.

A period in a clinical study during which subjects receive induction therapy. 